\title{
Evaluation of tests for antibody response in the follow-up of patients with acute and chronic forms of paracoccidioidomycosis
}

\author{
GILDA M. B. DEL NEGRO, CRISTIANE N. PEREIRA, HEITOR F. ANDRADE*, SELMA A. \\ PALACIOS, MÔNICA M. S. VIDAL, CECÍLIA E. CHARBEL and GIL BENARD†
}

Laboratório de Micologia Médica (LIM-53) and *Laboratório de Protozoologia (LIM-49), Instituto de Medicina Tropical de São Paulo and †Laboratório de Investigação Médica (LIM-56) and Clínica de Doenças Infecciosas e Parasitárias, Hospital das Clínicas da Faculdade de Medicina da Universidade de São Paulo, São Paulo, Brazil

\begin{abstract}
Several serological tests have been used successfully in the diagnosis of paracoccidioidomycosis (PCM). In contrast, data about the use of these tests in the follow-up of PCM patients have been heterogeneous. In this study, serum samples from 43 PCM patients with different clinical forms were analysed by counter-immuno-electrophoresis (CIE), complement fixation (CF) and ELISA before treatment. With CIE and ELISA, the chronic unifocal form showed significantly lower antibody levels compared with chronic multifocal and acute forms. Acute form patients had significantly higher titres than patients with multifocal disease by CIE but not by ELISA. No significant differences were observed with CF. Twenty-seven of these patients were followed-up for 2 years and showed a decline in antibody levels by all three tests, paralleling clinical improvement. However, only patients with unifocal disease cleared their antibodies after 1 year of treatment as analysed by CF and ELISA and after 2 years by CIE, suggesting that these patients may need shorter courses of therapy. Patients with the other clinical form of the disease needed $\geqslant 2$ years of therapy to clear their antibodies. Sera from a further five patients who presented with a relapse were analysed. At the time of relapse all showed increases in antibody levels by CIE and ELISA, but only three showed increases by CF tests. Therefore, CIE and ELISA demonstrated a better clinical correlation than CF, probably reflecting the fungal burden of PCM patients more accurately.
\end{abstract}

\section{Introduction}

Paracoccidioidomycosis (PCM) is one of the most important endemic deep mycoses in Latin A merica [1]. It is a chronic granulomatous disease caused by the dimorphic fungus Paracoccidioides brasiliensis. It has an important social and economic impact because it affects previously healthy men during their productive years, causing cutaneous or respiratory tract mucosal lesions, or both [1]. The infection is acquired by inhalation of conidiospores from the soil, but its reservoir has not yet been fully characterised [2]. The mucosal lesions can vary from isolated oral ulceration to diffuse interstitial pulmonary involvement. However, most patients present with multiple lesions located at

Received 4 Jan. 1999; revised version received 22 June 1999; accepted 23 June 1999.

Corresponding author: Dr G. Benard (e-mail: mahong@usp. br). different sites of the respiratory tract. This form of the disease, called chronic form (ChF), may develop many years after the patient has left the endemic area. In contrast, the less frequently seen acute form (AF) affects both sexes $<30$ years of age and probably develops soon after exposure to the fungus. Patients with the AF have visceral involvement, predominantly of the mononuclear-phagocytic system [1].

A ssessment of the serological response has long been used in PCM with two main purposes. Since its introduction by Moses in 1916 [3], it has been used mainly as a diagnostic tool, because in a significant proportion of the patients it is difficult to obtain clinical specimens to visualise or cultivate the fungus, or both, because only deep-sited lesions are present. Also, it has been used to follow up patients under treatment. Several techniques employing different antigenic preparations have been developed for diagnostic purposes and tested in different centres with 
good results [4]. In contrast, data on the use of serological tests in the follow-up of patients have been very heterogeneous. In the 1950s, Fava Neto first standardised the serological tests for both diagnosis and follow-up of PCM patients, the CF test and tube precipitation [5]. In the following decade, Restrepo introduced the double immunodiffusion (DID) test [6]. Counter-immuno-electrophoresis (CIE) and indirect immunofluorescence (IFI) tests appeared later $[7,8]$ and, more recently, ELISA and immunoblotting techniques have also been applied to the diagnosis and follow-up of PCM patients [9-13].

This study compared the CIE and complement fixation (CF) tests to an ELISA with a P. brasiliensis somatic antigen. While the CIE and CF tests have been used routinely for monitoring PCM patients receiving treatment [14], the ELISA has been introduced because it has the potential advantage of being more sensitive and allowing the processing of greater numbers of samples. Also, anti-P. brasiliensis antibody levels measured by the three assays were correlated with the different clinical presentations of the disease, and the literature on the use of serological tests to follow up PCM patients under treatment was reviewed.

\section{M aterials and methods}

\section{Patients and sera}

This study used serum samples from 43 patients with proven PCM : 27 patients were assayed before treatment and 6, 12 and 24 months after the initiation of therapy. Sera from the remaining patients were assayed only before treatment. The 27 patients were on regular antifungal therapy and were showing signs of clinical and mycological improvement, according to their clinical records. Samples were collected between 1991 and 1996 and maintained at $-20^{\circ} \mathrm{C}$ until the time of the study. The study also selected, from this same period, serum samples from five other patients who had relapses of the disease. Samples from these five patients were obtained at the start of therapy, when clinical improvement was observed, and when relapse was diagnosed clinically and mycologically. The patients were grouped according to the clinical forms of the disease, based on the classification proposed at the 3rd International Meeting on Paracoccidioidomycosis [15], as follows: 30 patients with the chronic (adult) form, comprising 23 with multifocal and 7 with unifocal lesions, and 13 patients with the acute (juvenile) form of PCM.

Serum samples from patients with other deep mycoses were used as controls in the development of the ELISA. This group comprised 20 cases of histoplasmosis, 15 cases of lobomycosis, 10 cases of cryptococcosis and six cases of aspergillosis. Serum samples $(n=65)$ from normal blood donors were used to establish the cut-off value for the ELISA.
Antigens

Two types of antigen were used in the study. The first was a 10-day crude filtrate obtained from the yeast phase of P. brasiliensis strain 113 (Culture Collection, Instituto de Medicina Tropical de São Paulo). The fungus was cultured in neopeptone $1.6 \%$, glucose $1.0 \%$, thiamine $0.01 \%$ and asparagine $0.02 \%$ liquid medium for 10 days at $36^{\circ} \mathrm{C}$ with shaking. The culture supernates were filtered through Whatman paper, concentrated 10-fold and dialysed against distilled water [14]. This culture filtrate antigen was employed in the DID, CIE and CF tests. For the ELISA, a cellular yeast extract (somatic antigen) was employed. It was prepared following a technique described previously [16]. B riefly, P. brasiliensis yeast cells (strains 113 and 339) were cultured in Fava N eto's agar medium at $36^{\circ} \mathrm{C}$ for 7 days. The cells were resuspended in $0.01 \mathrm{M}$ phosphate-buffered saline (PBS, pH 7.2) containing $10 \mathrm{~mm}$ phenylmethylsulphonylfluoride as a protease inhibitor. The cells were ruptured by maceration in the presence of glass beads and liquid nitrogen. After centrifugation at $10000 \mathrm{rpm}$ for $15 \mathrm{~min}$, the supernate was filtered through sterilising membranes, divided into small volumes and stored at $-20^{\circ} \mathrm{C}$ until use. Protein content was $1.97 \mathrm{mg} / \mathrm{ml}$ as determined by Lowry's method [17].

\section{Routine serological tests}

The DID test was performed in agar $1 \%$ gel in buffered saline $(\mathrm{pH}$ 6.9), containing sodium citrate $0.4 \%$ and glycine $7.5 \%$. The antigen $(12 \mu \mathrm{l})$ was placed in the central well and reference serum and patients' sera $(12 \mu \mathrm{l})$ in the surrounding wells. The slides were incubated for $48 \mathrm{~h}$, washed in saline, dried, and stained with Coomassie Brilliant Blue R (Sigma). The serum samples were tested undiluted [14]. CIE was performed in agarose $1 \%$ gel with electrophoresis in veronal-

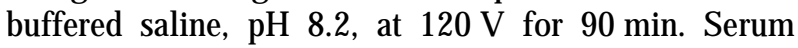
samples were applied to the anodic side and the antigen to the cathodic side of the slide. The sera were diluted two-fold and tested from the undiluted sample. Samples that reacted at least undiluted were considered positive [14]. The CF test was performed according to the Centers for Disease Control (CDC, A tlanta, USA) [18]. The results were considered positive when the titre was $\geqslant 1$ in 8 . These three tests have been used routinely in our laboratories, DID being the test of choice for diagnosis and CIE and CF mostly used for follow-up of PCM patients during treatment $[14,19]$.

\section{ELISA}

This assay was performed as described previously, with few modifications $[9,10]$. Briefly, polystyrene microplates (Corning, USA) were coated with $50 \mu \mathrm{l}$ of the cellular yeast extract, diluted in $0.06 \mathrm{M}$ carbonate buffer (pH 9.6) and incubated at $37^{\circ} \mathrm{C}$ in a humid chamber for $2 \mathrm{~h}$ at $4^{\circ} \mathrm{C}$ overnight. After five washes with PBS-Tween 
$200.05 \%$ (PBS-T), $50 \mu$ of the patients' sera diluted 1 in 200 in a solution of skim milk $5 \%$-gelatin $0.1 \%$ in PBS-T were added. After incubation for $2 \mathrm{~h}$ at $37^{\circ} \mathrm{C}$, plates were washed five times and $50 \mu \mathrm{l}$ of the goat antihuman IgG diluted 1 in 4000 (whole molecule; Sigma) conjugated with peroxidase were added to the wells. The plates were incubated at $37^{\circ} \mathrm{C}$ for a further $2 \mathrm{~h}$, washed again and the reaction was developed by the addition of 0-phenylenediamine- $\mathrm{H}_{2} \mathrm{O}_{2}$ as substrate. The absorbance was determined at $490 \mathrm{~nm}$ in a microplate reader (BioRad, USA) after stopping the reaction with $2 \mathrm{~N}$ $\mathrm{H}_{2} \mathrm{SO}_{4}$. All tests were performed in duplicate. The cutoff value was calculated from the mean +2 SD obtained with samples from normal blood donors $(n=65)$ tested at 1 in 200 dilution and was 0.1 OD units.

\section{Statistical analysis}

Serological titres were analysed as groups by the K ruskall-Wallis non-parametric test, after variance check. When appropriate, data were expressed as median of the groups. The comparison between groups was made by Dunn's test. All data were considered significant when $p<0.05$.

\section{R esults}

The DID was positive in $95.3 \%$ of the 43 patients included in this study. The two patients with negative results had localised disease and their diagnosis was made by biopsy. The ELISA with the somatic antigen was based on a previous report showing good results with an assay with a similar antigenic preparation [11]. In the present study, the ELISA showed high (100\%) sensitivity but, as described for other immunoenzymic assays, cross-reactions were observed with sera from patients with histoplasmosis and lobomycosis (Fig. 1) [9-11].

Results of the ELISA, CIE and CF tests on sera collected before therapy and grouped according to the clinical forms are summarised in Fig. 2.

L ow OD values for patients with the unifocal form were obtained in the ELISA, with three patients exhibiting values near the cut-off value. These results differed significantly from those of patients with the acute and chronic multifocal forms $(p<0.001)$. The OD values were distributed similarly in these latter two groups and no statistical difference was found between them.

Sera from all 43 patients showed positive results in the CIE test. The unifocal group showed significantly lower antibody titres, ranging from 2 to 16 . Of note, with this test there was no overlap in the antibody titres between the unifocal and the AF groups. In the latter group, the titres were always high, being $\geqslant 64$ and occasionally reaching 4096. Patients with multifocal disease exhibited a broader range of antibody titres, with low,

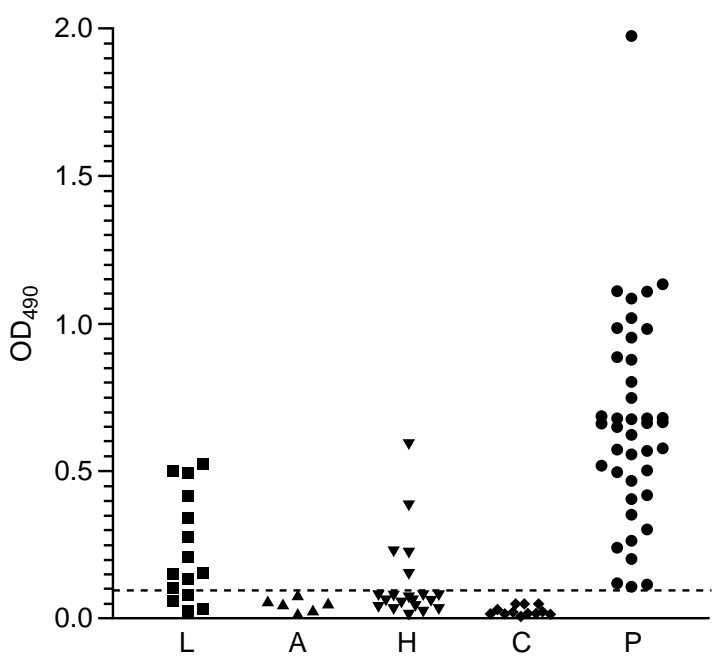

Fig. 1. OD 490 values determined by ELISA in serum samples (diluted 1 in 200) from different clinical groups: $(\boldsymbol{\square}, \mathrm{L})$ lobomycosis, $\mathrm{n}=15 ;(\boldsymbol{\Delta}, \mathrm{A})$ aspergillosis, $\mathrm{n}=6$; $(\boldsymbol{\nabla}, \mathrm{H})$ histoplasmosis, $\mathrm{n}=20 ;(\bullet, \mathrm{C})$ cryptococcosis, $\mathrm{n}=12 ;(0, \mathrm{P})$ paracoccidioidomycosis, $\mathrm{n}=43$. Dotted line represents the cut-off value, established as the mean +2 SD obtained with sera from 65 healthy blood donors.

intermediate and high values (8-256). Significant differences were also observed in the median antibody titres between multifocal and AF groups $(p<0.001)$.

In the CF test, sera from c. $50 \%$ of the patients with unifocal disease and AF exhibited negative results or antibody titres at the cut-off level. Indeed, low titres of CF antibodies in sera from AF patients with high titres in other reactions have been described previously $[14,19]$. As a result, AF patients presented either low or high antibody titres, with no intermediate values. The multifocal group, on the other hand, had a less heterogeneous distribution. As a consequence, significant differences were found only between unifocal and multifocal forms $(p<0.05)$.

For the follow-up studies, sera were collected after therapy for 6,12 and 24 months from 16 patients with the multifocal form, four with the unifocal form and seven with the acute form of the disease. These patients were on regular treatment during this follow-up period and had shown evidence of clinical improvement according to the patients' records. There were no relapses during this period. All three diagnostic techniques showed a similar trend, with decrease in antibody titres associated with therapy (Fig. 3).

With the ELISA, the reactivity of the AF group decreased sharply between the time of diagnosis and 6 months of therapy. After that, no evident decrease was observed until 24 months of therapy. The multifocal group presented a gradual decrease in reactivity until 24 months, when the median values were around 0.3, as for the AF group. The unifocal group exhibited low values at the beginning of the investigation, values near 
a

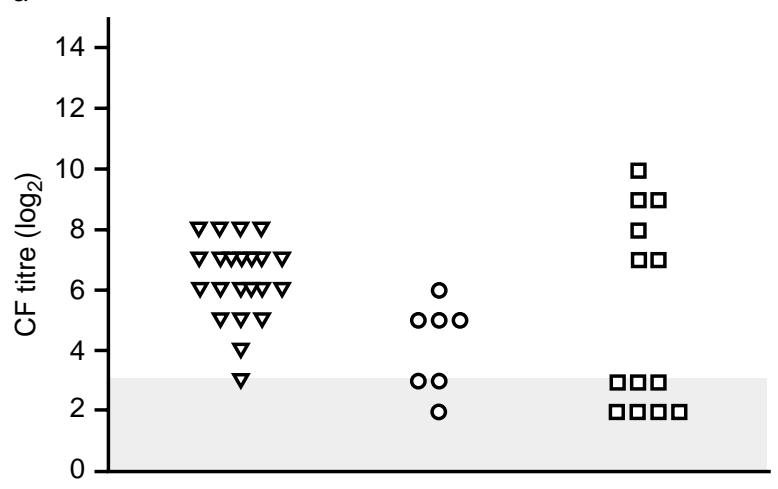

b

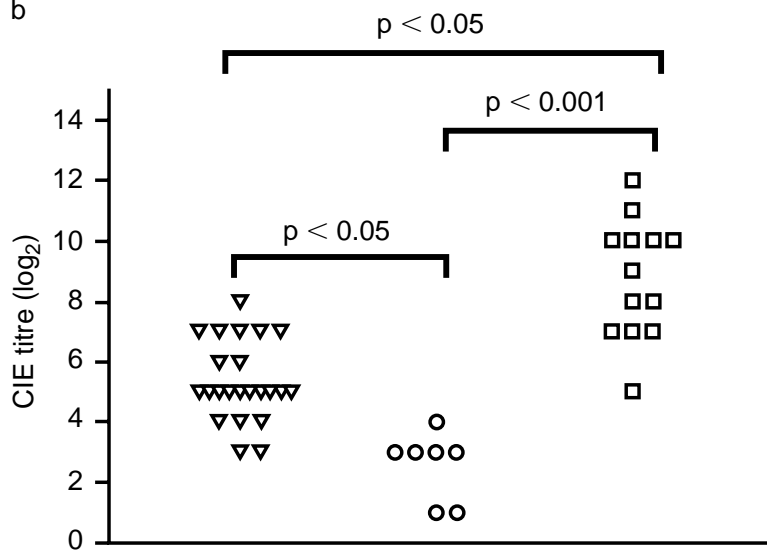

c

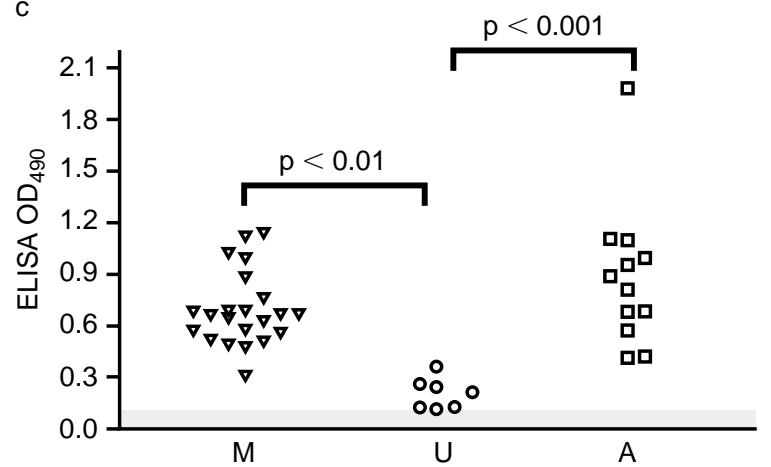

Fig. 2. Pre-treatment antibody levels determined by (a) CF, (b) CIE and (c) ELISA tests in sera of patients with different clinical forms of paracoccidioidomycosis. $(\nabla$, M), multifocal form; $(\circ, U)$, unifocal form; and $(\square, A)$, acute form. Dotted areas represent the cut-off values for CF and ELISA.

the cut-off after 1 year, and negative values after 2 years.

Sera from patients with the unifocal form of the disease had a median antibody titre of 8 when tested by CIE before treatment and 12 months after treatment, decreasing by only one dilution to 4 at 24 months. In contrast, patients with the AF showed an evident decrease, ranging from a median of 1024 before treatment began to 16 after 24 months. A decrease was also observed for the antibody titres in the multifocal group, dropping from 32 to 4 after the same length of therapy. Although patients in the AF
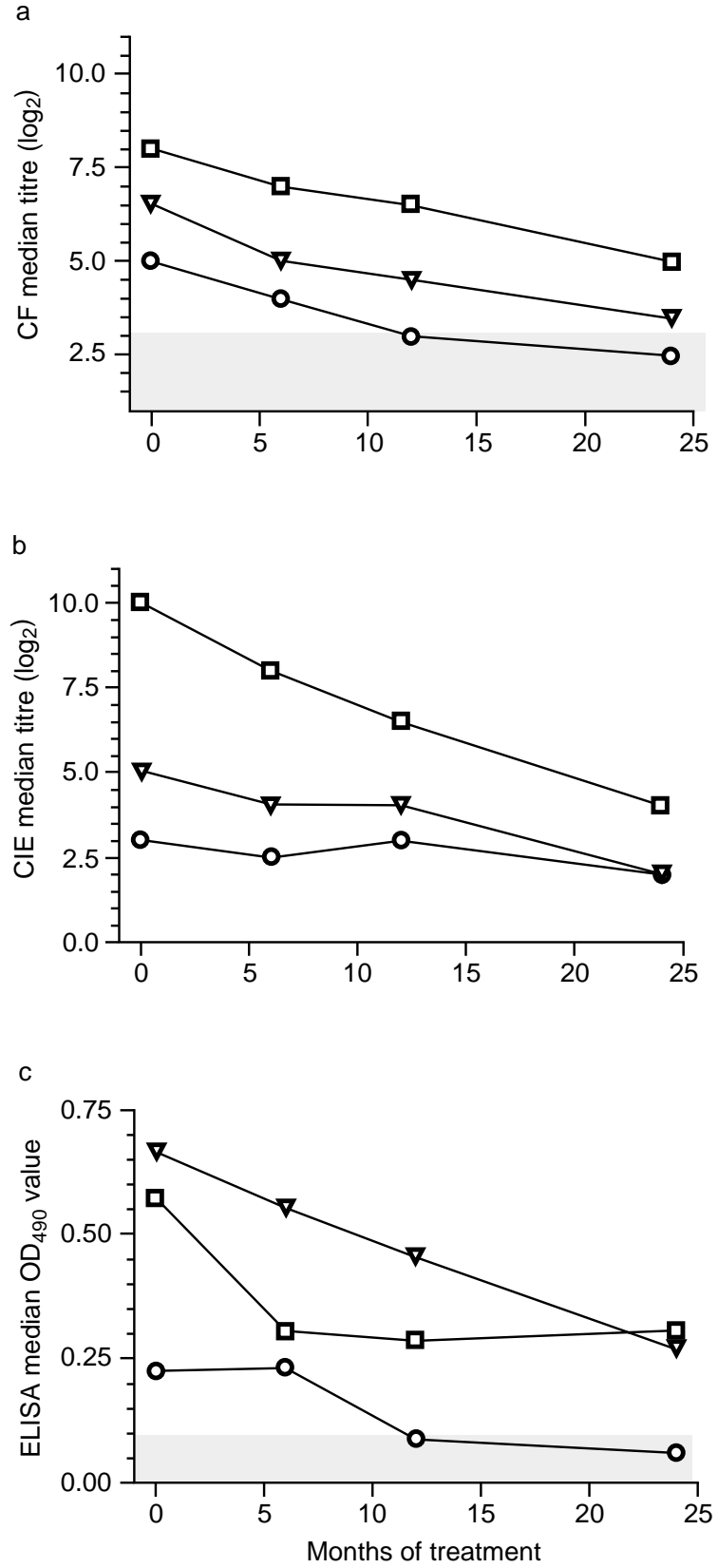

Fig. 3. Median values of the antibody levels before and during treatment determined by (a) CF, (b) CIE and (c) ELISA tests in sera of patients with different clinical forms of paracoccidioidomycosis. $(\nabla)$, multifocal form; (○), unifocal form; ( $\square)$, acute form. Dotted areas represent the cut-off values for CF and ELISA.

group showed a more marked decrease, after 2 years only patients with the chronic unifocal and multifocal forms had median antibody titres that could be considered as healing titres [20].

Sera from patients with all three clinical forms showed similar decrease with time in the antibody titres when the CF test was used, with unifocal patients showing the lowest titres. This last group exhibited negative results or titres near the cut-off value after treatment for 1 year. On the other hand, in the multifocal and AF groups titres were still positive after therapy for 12 
months, but after 24 months, only the former presented titres that could be considered as healing titres [20].

The serological evaluation of the five patients who relapsed during their follow-up is shown in Fig. 4. In both ELISA and CIE there was an evident increase in the antibody titres for all five patients, whereas in the CF test an increase in antibody titres was seen in only three patients.

\section{Discussion}

The first aim of this study was to compare the anti-P. brasiliensis antibody levels revealed by the three different tests in relation to the three clinical forms of the disease, i.e., $A F$, chronic multifocal and chronic unifocal. Of the three tests, only CIE distinguished the three groups, whereas the ELISA was able to distinguish only the chronic unifocal from the multi-
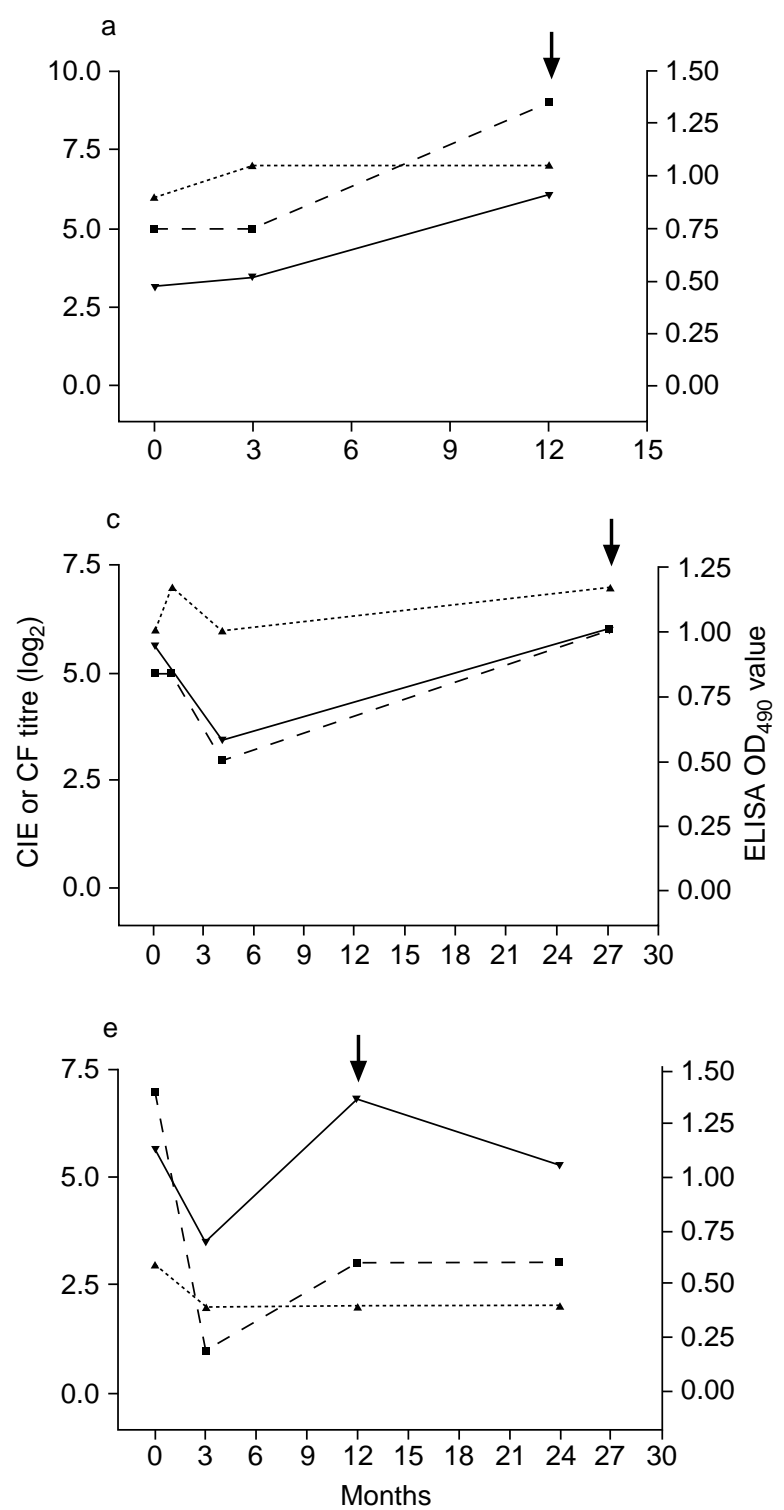

focal and AF groups. On the other hand, the CF test demonstrated significant differences in antibody titres only between the chronic multifocal and the chronic unifocal groups. Confirming previous results obtained by $C F$, half of the AF patients had low titres or no reactivity, similar to patients with the unifocal form of the disease $[14,19]$.

Correlation between the severity of the disease and high serological titres is commonly stated in the literature, but evidence is only anedoctal. Biagioni et al. used an indirect immunofluorescence assay and showed a tendency for an increase in IgG antibody titres from chronic localised to chronic disseminated and to AF patients [21]. Other authors found significantly higher IgG antibody levels in AF compared to ChF patients with ELISA [22]. The same authors also showed that antigen-specific IgM antibodies were associated with the AF, as suggested earlier by Barbosa et al. [23]. Although the present

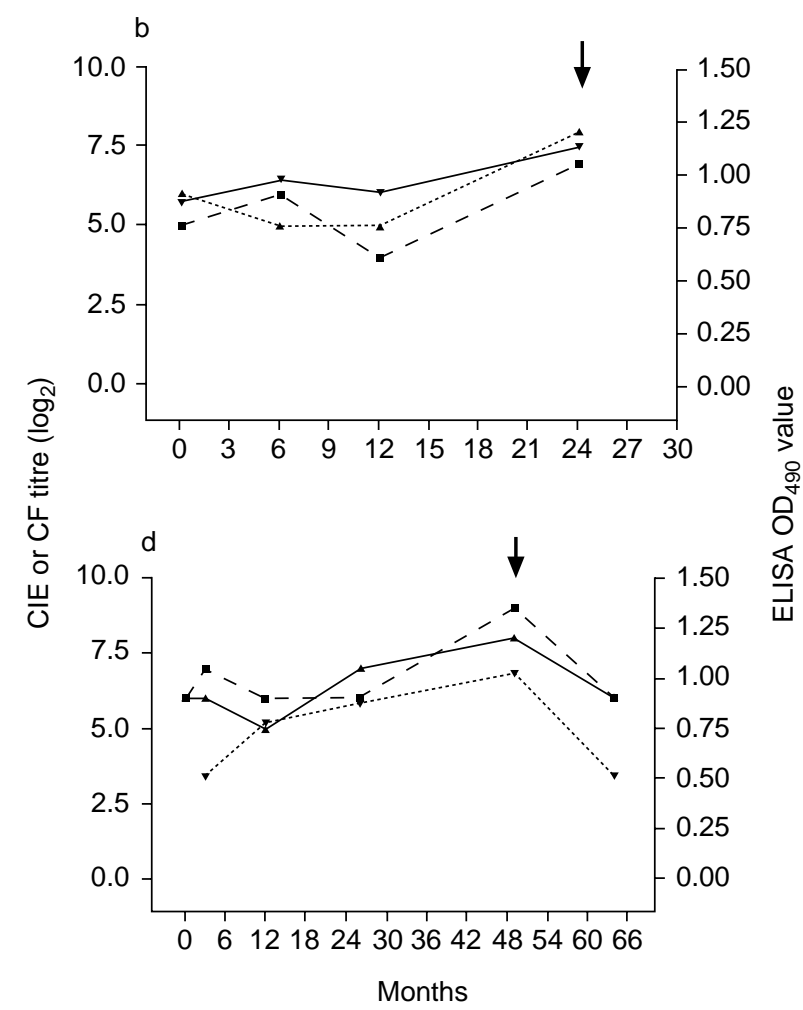

Fig. 4. Serological follow-up of five (a-e) paracoccidioidomycosis patients who relapsed during treatment. The arrows indicate when the clinical relapse was diagnosed. (……), CF; $(----), \mathrm{CIE} ;(---)$, ELISA. 
study did not find a difference between the chronic multifocal and AF patients in the ELISA, a statistical difference was seen when the two groups of ChF patients were grouped together and then compared with the AF patients (data not shown). Robles et al. analysed 142 patients, all except two with $\mathrm{ChF}$, and showed that severity of disease again correlated with higher antibody titres when three different methods were used - DID, CIE and CF [24]. Other authors did not find a relationship between antibody titres obtained by DID and involvement of specific organs in ChF patients [25]. However, in a recent study with DID, patients with severe disease presented a median titre of specific antibodies slightly lower than that of the control group, with less severe disease [26].

The association between severe disease and higher antibody response may be important in the assessment of patients' prognosis and treatment follow-up. As treatment of PCM lacks standardisation, it must be tailored to each patient. Even though patients are classified as having acute or chronic disease, a wide range of manifestations may appear in each form [15]. For example, patients with ChF disease may present with very localised to widely disseminated disease. In our experience, patients with localised disease are seen more rarely than those with multifocal disease, and usually present with oropharyngeal lesions and without significant involvement of the regional lymph nodes. The results of the present study reinforce the idea of a subgroup of patients whose disease results from reactivation of the fungus, in which the immune response checks, at least partially, the fungal dissemination and restricts it to only one site. These patients showed antibody titres consistently lower than patients with disseminated disease. The exclusion of the unifocal patients from the $\mathrm{ChF}$ group consequently left those patients with a pattern of disease that was closer to the AF cases. This was demonstrated in part by the lack of difference in the ELISA results between the chronic multifocal and the AF patients, although the same was not observed with CIE. Assuming that antibody titres correlate with antigenic load, the ELISA would indicate that both patient groups may have similar fungal burdens, whereas the CIE would indicate a higher fungal burden in the AF patients. In fact, many patients with the chronic multifocal form in this study had severely disseminated disease, and analysis by ELISA would provide a more reliable correlate of the fungal burden than analysis by $\mathrm{CIE}$.

These differences between CIE and ELISA were also observed when the serological response during treatment was analysed. All three tests showed that specific antibody titres decreased progressively during the 24 months of follow-up. However, the reactivity of patients' sera fell differently depending on the clinical form of the disease and the test employed. The ELISA again showed that patients with chronic multifocal and AF disease had a similar response, distinct from those with unifocal disease. The latter group already had negative results after therapy for 1 year, while the other patients presented significant antibody titres even after 2 years, although many of them could be considered clinically and mycologically cured. With the CIE assay, antibody titre curves were quite similar for patients with chronic unifocal and multifocal disease, with low titres after 1 year, and titres that may be considered as healing titres at 2 years. On the other hand, AF patients showed a more discrete reduction with low titres only after 2 years. Thus, the ELISA results would indicate that those patients with disseminated disease (chronic or acute) would need prolonged therapy ( $\geqslant 2$ years), whereas patients with localised disease would need shorter therapy, for c. 1 year. The CIE results, in turn, would indicate treatment for $\geqslant 2$ years for $\mathrm{ChF}$ patients and even longer for AF patients. In fact, immunologically, the ChF may represent a more subtle immune defect than the $A F$, since it results from reactivation of quiescent foci of the fungus $[27,28]$. These patients had been able, at least once in the past, to mount an efficient immune response, when first exposed to the fungus.

Follow-up of the serological response with the CF test showed that, as with the ELISA, patients with unifocal disease had results near the cut-off level after treatment for 1 year. The other patients still had positive tests after treatment for 2 years, as seen with $\mathrm{CIE}$ and ELISA. In addition to peculiarities of the serological response of each clinical form, the differences in the three tests may be due in part to differences in the antigens used for the ELISA (somatic) and for the CIE and CF (culture filtrate). The somatic antigen displays several fractions, ranging from 15.6 to $>94 \mathrm{kDa}$, which includes the $43-\mathrm{kDa}$ glycoprotein, but with no major fraction (data not shown). The crude filtrate antigen displayed fewer bands, gp43 being the major component [13].

The role of the serological response in the follow up of PCM patients is still a matter of debate, although the first studies with this aim published $>30$ years ago had already shown that clinical improvement was associated with a fall in specific antibody titres $[5,6]$. A large number of reports has been published since then; however, they have not added much to this initial statement. Restrepo et al. showed only partial improvement in the serological response after treatment for 6 months, with negative results for both the ID and the CF tests in only three of 16 patients studied. Although clinically and mycologically cured, most patients persisted with low antibody titres, a condition defined previously as healing antibody titres [29]. In fact, it was previously shown that PCM patients needed prolonged treatment to achieve complete cure and avoid relapses [30]. Lopes et al. showed that $72 \%$ of the patients cleared their anti- $P$. brasiliensis antibodies (by CF) after a mean length of treatment of C. 2 years, but some patients needed several years more of 
Table 1. Serological response during and after therapy of PCM patients in studies conducted by Brazilian investigators

\begin{tabular}{|c|c|c|c|c|c|c|}
\hline $\begin{array}{l}\text { Ref. } \\
\text { number }\end{array}$ & $\begin{array}{l}\text { Serological } \\
\text { tests }\end{array}$ & $\begin{array}{l}\text { Number of } \\
\text { patients } \\
\text { acute/chronic }\end{array}$ & $\begin{array}{l}\text { Therapy } \\
\text { follow-up } \\
\text { (months) }\end{array}$ & Serological response & $\begin{array}{l}\text { Follow-up } \\
\text { after therapy }\end{array}$ & Serological response \\
\hline 32 & $C F, T P$ & $\begin{array}{l}36 \text { Chronic? } \\
1 \text { Acute? }\end{array}$ & 3 & Decrease at 3 months with TP and CF & $\begin{array}{l}37 \text { patients for } 7 \text { months; } \\
\text { nine relapses }\end{array}$ & $\begin{array}{l}\text { Further decrease in TP and CF; serology vs } \\
\text { relapse: NI }\end{array}$ \\
\hline 33 & CF, TP, DID, CIE & $\begin{array}{l}10 \text { Chronic } \\
6 \text { Acute }\end{array}$ & $2-19$ & $\begin{array}{l}\text { Significant drop in CF, TP and CIE; DID } \\
\text { negativity in } 57 \% \text { at end of therapy }\end{array}$ & 12 months, no relapses & \\
\hline 34 & TP, CF & $\begin{array}{l}7 \text { Chronic } \\
3 \text { Acute }\end{array}$ & $10-19$ & $\begin{array}{l}\text { Significant drop in CF and negativity in TP } \\
\text { at end of therapy }\end{array}$ & 12 months, no relapses & $\ldots$ \\
\hline 35 & TP, DID, IIF & $\begin{array}{l}11 \text { Chronic } \\
1 \text { Acute }\end{array}$ & 18 & $\begin{array}{l}\text { Significant decrease in titres, but still positive } \\
\text { at low titres }\end{array}$ & 1-7 months, three relapses & $\begin{array}{l}\text { No correlation with relapses; but cured } \\
\text { patients with negative or stable low titres }\end{array}$ \\
\hline 36 & $C F, T P, I I F$ & $\begin{array}{l}43 \text { Chronic? } \\
4 \text { Acute? }\end{array}$ & .. & $\begin{array}{l}\text { CF was the best test to determine clinical cure, } \\
\text { clinical improvement or worsening }\end{array}$ & $\ldots$ & \\
\hline 37 & CF, TP, DID, IIF & $\begin{array}{l}8 \text { Chronic } \\
1 \text { Acute }\end{array}$ & $3-24$ & Three cases still persisted positive at 24 months & $\ldots$ & $\ldots$ \\
\hline 38 & CF, DID, IIF & $\begin{array}{l}37 \text { Chronic } \\
17 \text { Acute }\end{array}$ & 18 & $\begin{array}{l}\text { At } 6,12 \text { and } 18 \text { months, persisted unchanged in, } \\
\text { respectively, } 61 \%, 52 \% \text {, and } 45 \% \text { of the cases }\end{array}$ & $\ldots$ & $\ldots$ \\
\hline 39 & DID & $\begin{array}{l}8 \text { Chronic } \\
2 \text { Acute }\end{array}$ & $3.5-7$ & .. & 48-81 months, two relapses & $\begin{array}{l}\text { In } 6 \text { of } 7 \text { cured cases DID became negative; } \\
\text { DID not done in relapses }\end{array}$ \\
\hline 40 & DID & 21 Chronic & $6-18$ & Stable low titres at end of therapy & $\ldots$ & \\
\hline 41 & mELISA, CF, DID, CIE & $\begin{array}{l}14 \text { Chronic? } \\
2 \text { Acute? }\end{array}$ &. & $\ldots$ & 24 months & $\begin{array}{l}\text { mELISA and DID became negative with } \\
\text { clinical cure; FC and CIE tended to persist } \\
\text { positive }\end{array}$ \\
\hline 42 & CF, TP, DID, IIF & $\begin{array}{l}37 \text { Chronic } \\
8 \text { Acute }\end{array}$ & $\ldots$ & $\begin{array}{l}\text { Drop in DID was sharper than in PT and CF; } \\
\text { IIF: NI }\end{array}$ & $\begin{array}{l}\text { A) } 39 \text { patients for } 5 \text { years, } \\
\text { four relapses; } \\
\text { B) } 23 \text { patients for } 6-13 \text { years, } \\
\text { three relapses }\end{array}$ & $\begin{array}{l}\text { A) Negativity mainly in patients with } \\
\text { maintenance therapy; low titres in } 22 \text {; } \\
\text { B) Negativity in } 11 \text {, stable low titres in } 9\end{array}$ \\
\hline
\end{tabular}

CF, complement fixation; TP, tube precipitins; DID, double immunodiffusion; CIE, counter-immuno-electrophoresis; IIF, indirect immunofluorescence; mELISA, magnetic ELISA; NI, no information. 
continuous treatment [31]. More recent studies have shown that 7 years may elapse after the cessation of therapy before $75 \%$ of the patients have negative serology [25], and that IgG antibodies against the immunodominant $P$. brasiliensis antigen may still be detected in healed patients by Western blot [12]. With the advent of the imidazoles in the therapy of PCM, many studies were conducted that used serology to evaluate the efficacy of the different therapy regimens available. However, direct comparisons are difficult because protocols varied widely. Table 1 summarises the studies conducted by Brazilian investigators, whereas Table 2 displays those done by investigators from other South A merican countries. It can be seen from the tables [32-51], as well as from some other studies that specifically focused on the performance of serological techniques $[11,12,22,25,52-56]$, that antibody titres dropped with therapy but less frequently became negative when therapy was stopped or patients were considered clinically and mycologically cured, or both. In many reports, the fall in the antibody titres persisted even after withdrawal of the anti-fungal therapy. One report suggested that the titres after therapy correlated with the severity of the clinical manifestations before therapy [24]. This was also suggested in the present study: patients with more severe manifestations persisted with higher titres.

Of note is the observation that, by comparing the two tables, the patients enrolled in Brazilian studies tended to be more seriously ill, since in most series there were patients with the acute, more severe form of the disease. The AF seems to be very rare in the most southern part of and outside Brazil [57]. Also, treatment was generally more prolonged and, in some series, included maintenance therapy with sulphamides. Even so, relapses were more frequently recorded with the same drug treatments. The reasons for this higher severity of disease, whether related to regional variability in the virulence of the fungus or to the characteristics of the population at risk, are not known.

With few exceptions, serological documentation of the relapses was sparse and heterogeneous. Relapses or treatment failures could be either associated [22$25,35]$ or not [22] with increase in serological titres. In fact, relapses have al ready been documented for a long time in a few cases, despite CF negative results with therapy [20]. Therefore, the role of serology in the management of these cases remains unclear, and a particular titre or range of titres that would indicate when to stop therapy with no risk of relapse has not yet been defined in clinical practice [56]. The results of the present study, although based on a limited number of cases, suggest that when ELISA and another test such as CIE are used in combination, relapses or treatment failures can indeed be detected.

In conclusion, the assessment of the antibody response in PCM patients by CIE and ELISA showed a better

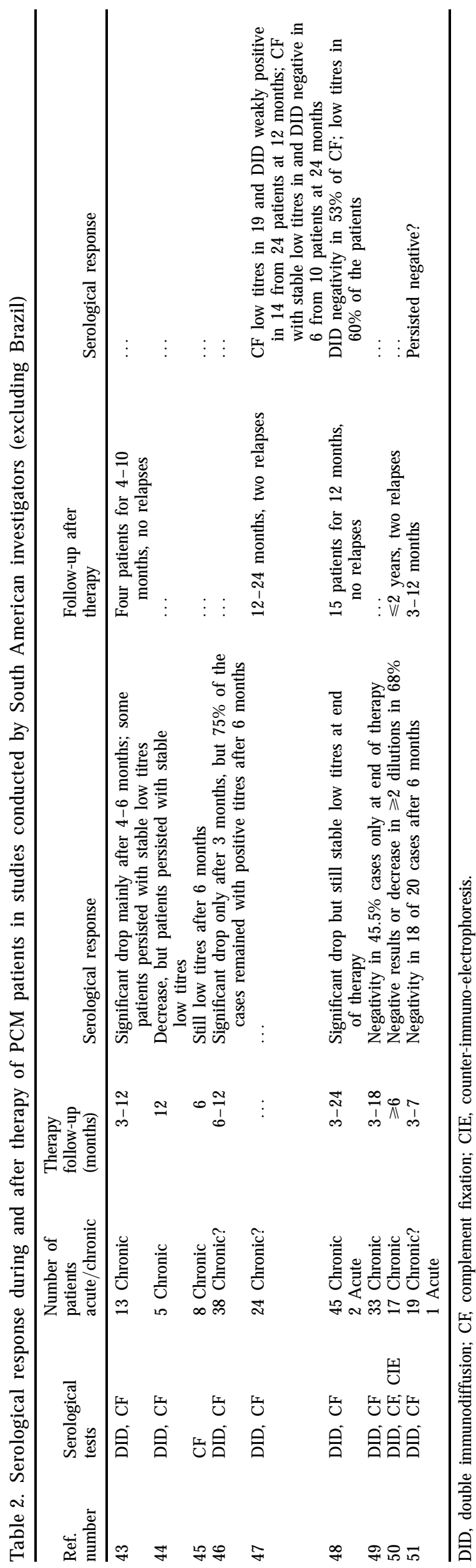


clinical correlation than CF. The former two tests correlated with the fungal burden at the time of diagnosis, distinguishing the different clinical forms. With therapy, the specific antibody titres fall, but less commonly disappear at the end of treatment or with clinical and mycological cure, irrespective of the serological test used. This was evident for the disseminated forms of the mycosis, either chronic or acute, which probably need more prolonged follow-up. Patients with unifocal disease could again be distinguished from those with disseminated disease by their serological response, as they needed a shorter period of therapy to clear their antibodies ( $\leqslant 1$ year). The results also suggest that relapses are associated with rising titres in the CIE or ELISA tests, or both. Finally, the definition of cure in PCM remains a matter of debate, and more prospective studies are needed. Other laboratory parameters, such as antigenaemia in urine or serum $[16,58,59]$, may help to define the time points to change or stop therapy more accurately.

We thank Luis V. Rizzo for careful review of the manuscript. This study was partially supported by Laboratórios de Investigação M édica, Hospital das Clínicas da FM USP.

\section{References}

1. Franco $M, M$ endes RP, Moscardi-Bacchi $M$, Reskallah-Iwasso $M$, M ontenegro MR. Paracoccidioidomycosis. Baillère's Clin Trop Med Communicable Dis 1989; 4: 185-200.

2. Restrepo MA. The ecology of Paracoccidioides brasiliensis: a puzzle still unsolved. Sabouraudia 1985; 23: 323-334.

3. Moses A. Fixação de complemento na blastomicose. Mem Inst O swaldo Cruz 1916; 8: 68-70.

4. Mendes-Giannini MA, Del Negro GB, Siqueira AM. Serodiagnosis. In: Franco M, Lacaz CS, Restrepo MA, Del Negro $G$ (eds) Paracoccidioidomycosis. B oca Raton, FL, CRS Press. 194: 345- 363.

5. Fava Neto C. Contribuição para o estudo imunológico da blastomicose de Lutz (Blastomicose sul-americana). Rev Inst Adolfo Lutz 1951; 21: 99-194.

6. Restrepo A. [The immunodiffusion technique in the diagnosis of paracoccidioidomycosis.] La prueba de inmunodifusín en el diagnostico de la paracoccidioidomicosis. Sabouraudia 1966; 4: $223-230$.

7. Siqueira AM. Diagnóstico imunológico. In: Del Negro G, Lacaz CS, Fiorillo AM (eds) Paracoccidioidomicose. Blastomicose Sul-A mericana. São Paulo, Sarvier-EDUSP. 1982: 253264.

8. Franco MF, Fava Neto C, Chamma LG. [Indirect immunofluorescent reaction for the serodiagnosis of South American blastomycosis. Standardisation of the reaction and comparison of results with the complement fixation test.] Reações de imunofluorescência indirecta para o diagnóstico sorológico de blastomicose sul-americana. Padronização da reação e comparação dos resultados com fixação de complemento. Rev Inst Med Trop Sao Paulo 1973; 15: 393-398.

9. Mendes-Giannini MJS, Camargo ME, Lacaz CS, Ferreira AW. Immunoenzymatic absorption test for serodiagnosis of paracoccidioidomycosis. J Clin Microbiol 1984; 20: 103-8.

10. de Camargo ZP, Guesdon JL, Drouhet E, Improvisi L. Enzymelinked immunosorbent assay (ELISA) in paracoccidioidomycosis. Comparison with counterimmunoelectrophoresis and erythro-immunoassay. Mycopathogia 1984; 88: 31- 37.

11. Cano LE, Brummer $E$, Stevens $D A$, Restrepo A. An evaluation of the enzyme-linked immunoabsorbent assay (ELISA) for quantitation of antibodies to Paracoccidioides brasiliensis. J Med Vet Mycol 1986; 24: 467-475.

12. M endes-Giannini MJS, Bueno JP, Shikanai-Yasuda MA et al. Antibody response to the $43 \mathrm{KDa}$ glycoprotein of Paracocci- dioides brasiliensis as a marker for the evaluation of patients under treatment. Am J Trop Med Hyg 1990; 43: 200-206.

13. Camargo ZP, Unterkircher $C$, Travassos LR. Identification of antigenic polypeptides of Paracoccidioides brasiliensis by immunoblotting. J Med Vet Mycol 1989; 27: 407-412.

14. Del Negro GMB, Garcia NM, Rodrigues EG et al. The sensitivity, specificity and efficiency values of some serological tests used in the diagnosis of paracoccidioidomycosis. Rev Inst Med Trop Sao Paulo 1991; 33: 277-280.

15. Franco $M, M$ ontenegro $M R, M$ endes RP, Marques $A S$, Dillon NL, M otta NGS. Paracoccidioidomycosis: a recently proposed classification of its clinical forms. Rev Soc Bras Med Trop 1987: 20: 129- 132

16. Freitas-da-Silva $G \&$ Roque-Barreira MC. Antigenemia in paracoccidioidomycosis. J Clin Microbiol 1992; 30: 381-385.

17. Lowry $\mathrm{OH}$, Rosenbrough $\mathrm{NJ}$, Farr $\mathrm{AL}$, Randall RJ. Protein measurement with the Folin phenol reagent. I Biol Chem 1951; 193: 265- 275.

18. Palmer DF, Kaufman L, Kaplan W, Cavallaro JJ. The complement fixation test. In: Serodiagnosis of mycotic diseases. Springfield, Charles C Thomas. 1977: 155-181.

19. Restrepo MA, Moncada LH. Serologic procedures in the diagnosis of paracoccidioidomycosis. Proceedings of the International Symposium on Mycoses. Scientific Publication PAHO. 1970; 205: 101-110.

20. Fava Neto C. [Paracoccidioidomycosis immunology.] Imunologia da paracoccidioidomicose. Rev Inst Med Trop Sao Paulo 1976: 18: 42-53

21. Biagioni L, Souza MJ, Chamma LG et al. Serology of paracoccidioidomycosis. II. Correlation between class-specific antibodies and clinical forms of the disease. Trans R Soc Trop Med Hyg 1984; 78: 617-621.

22. Bueno JP, Mendes-Giannini MJS, Del Negro GMB et al. IgG, IgM and IgA antibody response for the diagnosis and followup of paracoccidioidomycosis: comparison of counterimmunoelectrophoresis and complement fixation. J Med Vet Mycol 1997; 35: 213-217.

23. Barbosa SFC, Takeda AK, Chacha J, Cucé LC, Fava Netto C. Anticorpos específicos das classes IgG, IgM e IgA para Paracoccidioides brasiliensis dosados através da reação de imunofluorescência indireta no soro de pacientes e sua correlação com o tempo de evolução e forma clínica da doença. Rev Inst Adolfo Lutz 1981; 41: 121-126.

24. Robles AM, A rechavala AI, Negroni $R$, Finquelievich $J$. Estudio de algunas tecnicas inmunologicas en pacientes com paracoccidioidomicosis. Rev Arg Micologia 1990; 13: 15- 25.

25. Ferreira-da-Cruz MF, Francesconi-do-Vale AC, Espinera MCD Wanke B, Galvão-Castro B. Study of antibodies in paracoccidioidomycosis: follow-up of patients during and after treatment. J Med Vet Mycol 1990; 28: 151-157.

26. M eira DA, Pereira PCM , M arcondes-M achado J et al. The use of glucan as immunostimulant in the treatment of paracoccidioidomycosis. Am J Trop Med Hyg 1996; 55: 496-503.

27. Mota NGS, Rezkallah-Iswasso MT, Peraçoli MTS et al Correlation between cell-mediated immunity and clinical forms of paracoccidioidomycosis. Trans R Soc Trop Med Hyg 1985; 79: $765-772$.

28. Benard G, Hong MA, Del Negro GMB, Batista L, ShikanaiYasuda MA, Duarte AJS. Antigen-specific immunosuppression in paracoccidioidomycosis. Am J Trop Med Hyg 1996; 54: 7- 12.

29. Restrepo A, Restrepo $M$, de Restrepo $F$, A ristizábal $L H$, M oncada LH, Vélez $H$. Immune responses in paracoccidioidomycosis. A controlled study of 16 patients before and after treatment. Sabouraudia 1978; 16: 151- 163.

30. Machado Filho J, Miranda RL. Considerações relativas à blastomicose sul-americana. Evolução, resultados terapêuticos e moléstias associadas em 394 casos consecutivos. O Hospital 1961; 60: 375-412.

31. Lopes CF. Evaluación de los resultados obtenidos en el tratamiento de la blastomicosis sudamericana com sulfamida de administración semanal. Medicina Cutánea 1971; 5: 357-366.

32. Cucé LC, Wroclawski EL, Sampaio SAP. Treatment of paracoccidioidomycosis with ketoconazole. Rev Inst Med Trop Sao Paulo 1981; 23: 82-85.

33. Del Negro G. Ketoconazole in paracoccidioidomycosis. A long-term therapy study with prolonged follow-up. Rev Inst Med Trop Sao Paulo 1982; 24: 27-39. 
34. Gomes MCO. [Treatment of paracoccidioidomycosis with ketocoinazole.] Tratamento da paracoccidioidomicose com ketoconazol. Rev Inst Med Trop Sao Paulo 1983; 25: 127-132.

35. M arcondes ], Meira DA, M endes RP et al. [Evaluation of the treatment of paracoccidioidomycosis with ketoconazole.] Avaliação do tratamento da paracoccidioidomicose com o ketoconazol. Rev Inst Med Trop Sao Paulo 1984; 26: 113-121.

36. Campos EP, Sartori JC, Hetch ML, de Franco M F. Clinical and serologic features of 47 patients with paracoccidioidomycosis treated by amphotericin B. Rev Inst Med Trop Sao Paulo 1984; 26: $212-217$.

37. Dillon NL, Habermann MC, M arques SA et al. Ketoconazole. Tratamento da paracoccidiodomicose no período de dois anos. An Bras Dermatol 1985; 60: 45-48.

38. $M$ arques SA, Dillon NL, Franco MF et al. Paracoccidioidomycosis: a comparative study of the evolutionary serologic clinical and radiologic results for patients treated with ketoconazole or amphotericin B plus sulfonamides. Mycopathologia 1985; 89: 19-23.

39. Lima NS, Francesconi-do-Valle AC. Ketoconazol na paracoccidioidomicose com longo seguimento pós-terapêutico. An Bras Dermatol 1987; 62: 205-207.

40. Barraviera $B$, Mendes RP, Machado JM, Perreira PCM, de Souza MJ, Meira DA. Evaluation of treatment of paracoccidioidomycosis with cotrimazine (combination of sulfadiazine and trimethoprim). Preliminary report. Rev Inst Med Trop Sao Paulo 1989; 31: 53-55.

41. Campos EP, Dib Neto J, Unterkircher C, Camargo ZP Serological evaluation in follow-up of the paracoccidioidomycosis patients. Rev Microbiol 1990; 21: 11-17.

42. Campos EP, Campos N eto PP, Franco M F, M aestà I. Avaliação clínico-sorológica de 45 doentes com Paracoccidioidomicose. Folha Médica (Br) 1992; 104: 207-211.

43. Restrepo A, Stevens DA, Gómez I et al. Ketoconazole: a new drug for the treatment of paracoccidioidomycosis. Rev Infect Dis 1980; 2: 633-642.

44. Restrepo A, Stevens DA, Leiderman $E$ et al. Ketoconazole in paracoccidioidomycosis: efficacy of prolonged oral therapy. Mycopathologia 1980; 72: 35-45.

45. Restrepo A, Gómez I, Robledo MA. [Efficacy of ketoconazole in patients with recurrent paracoccidioidomycosis.] Eficacia del ketoconazol en pacientes com paracoccidioidomicosis recidivante. Rev Inst Med Trop Sao Paulo 1982; 24: 173-179.

46. Restrepo A, Gómez I, Cano LE et al. Treatment of paracoccidioidomycosis with ketoconazole: a three-year experience. Am J Med 1983; 74: 48-52.
47. Restrepo A, Gomez I, Cano LE et al. Post-therapy status of paracoccidioidomycosis treated with ketoconazole. Am J Med 1983; 78: 53- 57.

48. Naranjo MS, Trujillo M, M unera MI, Restrepo P, Gómez I, Restrepo A. Treatment of paracoccidioidomycosis with itraconazole. I Med Vet Mycol 1990; 28: 67-76.

49. Negroni R, Robles AM, A rechavala A, Tuculet MA, Galimberti $R$. Ketoconazole in the treatment of paracoccidioidomycosis and histoplasmosis. Rev Infect Dis 1980; 2: 643-649.

50. Negroni R, Palmieri O, Koren F, Tiraboschi IN, Galimberti RL. Oral treatment of paracoccidioidomycosis and histoplasmosis with itraconazole in humans. Rev Infect Dis 1987; 9 suppl 1: S47-S50.

51. Vargas J, Recacoechea M. Ketoconazole in the treatment of paracoccidioidomycosis (South American blastomycosis). Experience in 30 cases in Bolivia. Mycoses 1988; 31: 187-197.

52. Negroni R, Robles AM, A rechavala AI. Criterios para la interrupción del tratamiento com ketoconazol en la paracoccidioidomicosis. Rev Arg Micol 1983; 6: 14-17.

53. Cano LE, Restrepo A. Predictive value of serologic tests in the diagnosis and follow-up of patients with paracoccidioidomycosis. Rev Inst Med Trop Sao Paulo 1987; 29: 276- 283.

54. Mistreta T, Souza MJ, Chamma LG, Pinho SZ, Franco M. Serology of paracoccidioidomycosis. I. Evaluation of the indirect immunofluorescent test. Mycopathologia 1985; 89: 13-17.

55. $M$ artins $R$, $M$ arques $S$, Alves $M$, Fecchio $D$, de Franco $M F$. Serological follow-up of patients with paracoccidioidomycosis treated with itraconazole using Dot-blot, ELISA and westernblot. Rev Inst Med Trop Sao Paulo 1997; 39: 261-269.

56. Restrepo A. Report of activities of the committee on paracoccidioidomycosis serodiagnosis. ISHAM Mycoses Newsletter 1992; 59: 4.

57. Wanke B, Londero AT. Epidemiology and paracoccidioidomycosis infection. In: Franco M, Lacaz CS, Restrepo MA, Del Negro $G$ (eds) Paracoccidioidomycosis. Boca Raton, FL, CRS Press. 1994: 109-120

58. Gómez BL, Figueroa JI, Hamilton AJ et al. Use of monoclonal antibodies in diagnosis of paracoccidioidomycosis: new strategies for detection of circulating antigens. J Clin Microbiol 1997; 35: 3278-3283.

59. Salina MA, Shikanai-Yasuda MA, Mendes RP, Barraviera $B$ Mendes Giannini MJS. Detection of circulating Paracoccidioides brasiliensis antigen in urine of paracoccidioidomycosis patients before and during treatment. J Clin Microbiol 1998; 36: $1723-1728$. 